\title{
Play Therapy Untuk anak-anak Korban Bencana Alam Yang Mengalami Trauma (Post Traumatic Stress Disorder/PTSD)
}

\author{
Endah Nawangsih \\ Universitas Islam Bandung. J1. Tamansari No. 1 Bandung 40116 \\ e-mail : nawangsihendah@yahoo.com
}

\begin{abstract}
Anywhere in the world, natural disasters events cause loss of life, moreover a deep sorrow and fear for the victims. They were in a state of very uneasy, very scared, never-ending anxiety, and become prone to panic. These conditions called post-traumatic stress disorder (PTSD) as a continuous maladaptive reaction to a traumatic experience. In contrast to adults, children are in a state highly vulnerable to the impact caused by a traumatic event. Children with PTSD may show confusion or agitation. This condition brings suffering prolonged, if not given proper treatment. It required a specific intervention design for children with PTSD namely Play Therapy techniques. This intervention is one way that can be used to understand the world of children through playing, so that when used in the right circumstances can be meaningful as physical activity as well as therapy.
\end{abstract}

Keywords: disaster, PTSD, children, play therapy

\begin{abstract}
Abstrak
Peristiwa-peristiwa bencana alam di belahan dunia mana pun tidak saja menimbulkan korban jiwa, tetapi duka yang mendalam, serta ketakutan yang mendalam. Para korban merasa berada pada kondisi yang sangat tidak tenang, merasa sangat takut, kegelisahan yang tidak berkesudahan, dan menjadi mudah mengalami panik.

Kondisi-kondisi tersebut merupakan gangguan pasca trauma (Post traumatic stress disorder/PTSD) yaitu reaksi maladaptif yang berkelanjutan terhadap pengalaman traumatis. Berbeda dengan orang dewasa, anak-anak berada dalam kondisi sangat rentan terhadap dampak yang ditimbulkan oleh suatu peristiwa yang menimbulkan trauma.

Anak-anak dengan PTSD kemungkinan menunjukkan kebingungan atau agitasi. Kondisi ini membawa penderitaan yang berkepanjangan, apabila tidak diberikan penanganan yang tepat. Diperlukan rancangan intervensi khusus bagi anak-anak yang mengalami PTSD yakni teknik Play Therapy. Intervensi ini adalah salah satu cara yang dapat digunakan dalam memahami dunia anak-anak melalui permainan, sehingga bila digunakan pada situasi dan kondisi yang tepat dapat bermakna sebagai kegiatan fisik sekaligus sebagai terapi.
\end{abstract}

Kata kunci: bencana, gangguan pasca trauma, anak-anak, play therapy

\section{PENDAHULUAN}

Peristiwa bencana alam yang terjadi di Indonesia mulai awal tahun 2009 hingga saat ini masih menyisakan duka yang mendalam. Berbagai bencana, seperti bencana banjir, peristiwa gempa yang terjadi di berbagai kepulauan di Indonesia, juga peristiwa kebakaran tempat tinggal dan kebakaran hutan. Peristiwa-peristiwa tersebut tidak saja menimbulkan korban jiwa, tetapi juga korban dan keluarga korban mengalami perasaan duka yang mendalam, serta ketakutan yang amat mendalam. Banyak diantara korban bencana alam, kehilangan orang-orang yang dicintai, serta kehilangan harta benda. Banyak pula diantara korban bencana alam mengalami kecelakaan fisik dan gangguan mental.

Berbagai peristiwa bencana yang menimbulkan duka yang mendalam tersebut, membuat para korban bencana alam merasa berada pada kondisi yang sangat tidak tenang, merasa sangat takut, kegelisahan yang tidak berkesudahan. Selain itu, para korban pun menjadi mudah me- 
ngalami panik. Serangan-serangan panik melibatkan reaksi kecemasan yang intens disertai dengan simtom-simtom fisik, seperti jantung berdebar-debar, nafas cepat, nafas tersengal-sengal atau kesulitan bernafas, berkeringat banyak dan rasa lemas serta pusing. Serangan-serangan ini disertai dengan perasaan teror yang luar biasa dan perasaan akan adanya bahaya yang segera menyerang atau ada malapetaka yang akan segera menimpa serta juga disertai dengan suatu dorongan untuk melarikan diri dari situasi ini.

Perasaan duka yang mendalam yang dialami oleh korban setelah mengalami bencana menimbulkan trauma yang mendalam, para korban mengalami suatu reaksi maladaptif yang terjadi sesudah mengalami pengalaman traumatik. Reaksi yang maladatif ini kemungkinan dapat berlangsung berbulan-bulan, bertahuntahun, dan mungkin baru muncul setelah beberapa bulan atau tahun setelah adanya pemaparan terhadap peristiwa traumatis.

Meskipun kebanyakan individu atau korban yang mempunyai pengalaman traumatis sampai taraf tertentu mengalami distres psikologis, tidak semua korban trauma mengembangkan ciri-ciri post traumatic syndromes disorders (PTSD). Tetapi, banyak yang menderita hal itu. Kerentanan terhadap PTSD kemungkinan tergantung pada faktor-faktor seperti resiliensi dan kerentanan terhadap efek trauma, keparahan trauma, derajat pemaparan, ketersediaan dukungan sosial, penggunaan respons coping aktif dalam menghadapi stres traumatis, dan perasaan malu.

Para korban yang mengalami PTSD cenderung mempunyai resiko yang tinggi untuk menderita gangguan psikologis tertentu, seperti depresi mayor, gangguan panik, dan fobia sosial. Pada kasus traumatis yang disebabkan oleh tindak kekerasan dan mengalami pelecehan seksual, penderita cenderung menunjukkan keinginan bunuh diri yang tinggi. Dengan demikian dapat dipahami akan kerugian emosional yang luar biasa tinggi yang sangat tidak diharapkan diderita oleh para korban bencana itu. Diperlukan upaya penanganan terhadap korban bencana alam yang masih terus-menerus dilakukan.

Secara umum pengertian trauma berkaitan dengan cedera fisik, kerusakan jaringan, luka atau shock. Sedangkan trauma secara psikologis diartikan sebagai kecemasan hebat dan mendadak akibat peristiwa di lingkungan seseorang yang melampaui batas kemampuannya untuk bertahan, mengatasi atau menghindar (Nevid,2005). Dengan demikian, PTSD merupakan sindrom kecemasan, labilitas autonomik, kerentanan emosional, dan kilas balik dari pengalaman yang amat pedih setelah stres fisik maupun emosi yang melampaui batas ketahanan orang biasa.

National Institute of Mental Health (NIMH) mendefinisikan PTSD sebagai gangguan berupa kecemasan yang timbul setelah seseorang mengalami peristiwa yang mengancam keselamatan jiwa atau fisiknya. Peristiwa trauma ini bisa berupa serangan kekerasan, bencana alam yang menimpa manusia, kecelakaan, atau perang (Nevid, 2005). Dengan demikian PTSD dapat meliputi kondisi yang muncul setelah pengalaman luar biasa mencekam, mengerikan dan mengancam jiwa seseorang, misalnya peristiwa bencana alam, kecelakaan hebat, sexual abuse, atau perang.

Secara umum gejala-gejala yang sering dialami korban PTSD adalah sebagai berikut:

1. Pengulangan pengalaman trauma, ditunjukkan dengan selalu teringat akan peristiwa yang menyedihkan yang telah dialami itu, ada flashback (merasa seolah-olah peristiwa yang menyedihkan terulang kembali), nightmares (mimpi buruk tentang kejadian-kejadian yang membuatnya sedih), reaksi emosional dan fisik yang berlebihan karena dipicu oleh kenangan akan peristiwa yang menyedihkan

2. Penghindaran stimuli yang diasosiasikan dengan pengalaman traumatik 
atau mati rasa dalam responsivitas. Seseorang yang mengalami trauma menghindari untuk berpikir tentang trauma atau tentang stimulus yang mengingatkan pada kejadian tersebut. Mati rasa adalah menurunnya ketertarikan pada orang lain, suatu rasa keterpisahan, dan ketidakmampuan untuk merasakan berbagai emosi positif.

3. Ketegangan yang meningkat, ditunjukkan dengan susah tidur atau mempertahankan tidur, mudah marah atau tidak dapat mengendalikan marah, sulit berkonsentrasi, kewaspadaan yang berlebih, respon kejut yang berlebihan atas segala sesuatu (Nevid, 2005)

\section{KAJIAN TEORI}

\section{Kriteria Diagnostik PTSD}

Beberapa peristiwa besar yang terjadi atau yang dialami dalam kehidupan seseorang, baik peristiwa yang menyenangkan maupun yang menimbulkan perasaan yang tidak menyenangkan, akan memberikan perubahan pada kehidupan individu sebagai akibat yang dialaminya. Perubahan-perubahan tersebut dapat menimbulkan stres. Stres yang dialami dapat menimbulkan adanya tekanan atau tuntutan yang dialami individu agar ia beradaptasi atau menyesuaikan diri. Stres berimplikasi secara luas pada masalahmasalah fisik maupun psikologis.

Efek dari stres dapat menimbulkan gangguan penyesuaian yang menyangkut reaksi maladaptif terhadap stres. Pada gangguan penyesuaian, individu mempunyai kesulitan untuk menyesuaikan diri dengan stresor dalam hidup, seperti masalah pekerjaan, perceraian, penyakit kronis, atau rasa duka cita yang mendalam setelah mengalami kehilangan. Kondisi tersebut dapat menimbulkan gangguan stres akut (acute stress disorder/ASD). ASD adalah suatu reaksi maladaptif yang terjadi pada bulan pertama sesudah pengalaman traumatis. Sedangkan gangguan stres pascatrauma (post traumatic stress disorder/PTSD) adalah reaksi maladaptif yang berkelanjutan terhadap suatu pengalaman traumatis. Berlawanan dengan ASD, PTSD kemungkinan berlangsung berbulan-bulan, bertahun-tahun, dan mungkin baru muncul setelah beberapa tahun setelah adanya pemaparan terhadap peristiwaperistiwa traumatis. Kedua tipe gangguan ini terdapat pada orang-orang yang telah menjadi saksi dari hancurnya rumahrumah dan lingkungan hidup mereka oleh bencana alam, seperti banjir, gempa bumi, tornado, dan sebagainya.

Pada ASD dan PTSD peristiwa traumatis tersebut melibatkan kematian atau ancaman kematian atau cedera fisik yang serius, atau ancaman terhadap keselamatan diri sendiri atau orang lain. Respon terhadap ancaman tersebut mencakup perasaan takut yang intens, perasaan tidak berdaya, atau perasaan resa ngeri (horor). Anak-anak dengan PTSD kemungkinan mengalami ancaman ini dengan cara lain, misalnya dengan menunjukkan kebingungan atau agitasi. Meskipun kebanyakan orang yang mempunyai pengalaman traumatis sampai pada taraf tertentu mengalami distres psikologis, tidak semua korban trauma mengembangkan ASD atau PTSD.

Ciri-ciri reaksi stres ASD dan PTSD mempunyai banyak ciri dan simtom yang sama, beberapa ciri yang sama adalah mengalami kembali peristiwa traumatis, menghindari petunjuk atau stimuli yang diasosiasikan dengan peristiwa tersebut, mati rasa dalam responsivitas secara umum atau dalam segi emosional, gangguan fungsi atau distres emosional yang penting. Sedangkan perbedaan utama antara kedua gangguan tersebut adalah pada ASD penekanannya ada pada disosiasi, yaitu perasaan asing terhadap diri sendiri atau terhadap lingkungannya. Individu yang mengalami gangguan stres akut mungkin merasakan dunia ini seolaholah sebagai suatu tempat dalam mimpi atau suatu tempat yang tidak nyata. Dalam gangguan stres akut (ASD), individu mungkin juga tidak dapat melaksanakan tugas-tugas yang perlu, seperti misalnya 
mendapatkan bantuan medis atau bantuan hukum yang diperlukan (Nevid, 2005).

Kriteria diagnostik untuk gangguan stres akut (ASD) berdasarkan Diagnotic and Statistical Manual of Mental Disorders III-Revised (DSM III-R), dapat memperlihatkan kondisi traumatik seseorang adalah sebagai berikut :

1. Orang yang terpapar dengan suatu kejadian traumatik, dimana kedua dari ciri berikut ini dapat ditemukan, yaitu orang yang mengalami, menyaksikan atau dihadapkan dengan kejadian yang berupa ancaman kematian atau kematian yang sesungguhnya atau cedera yang serius atau ancaman kepada integritas fisik diri sendiri atau orang lain, atau respon berupa rasa takut yang kuat dan rasa tidak berdaya atau selalu dihantui perasaan takut yang berlebihan.

2. Merupakan salah satu keadaan dari ketika seseorang mengalami atau setelah mengalami kejadian yang menakutkan, maka individu akan memiliki tiga atau lebih gejala disosiatif yang berupa perasaan subyektif kaku, tidak ada responsivitas emosi, penurunan kesadaran sekelilingnya, derealisasi, depersonalisasi, amnesia disosiatif (tidak mampu mengingat aspek penting dari trauma).

3. Kejadian traumatik yang secara bertahap dialami kembali dalam sekurangnya salah satu dari trauma yang berupa bayangan, pikiran, mimpi, ilusi, episode kilas balik yang berulang-ulang atau suatu perasaan pengalaman hidup yang muncul kembali, pengalaman atau penderitaan saat terpapar dengan pengingat kejadian traumatik.

4. Penghindaraan pada stimuli yang menyadarkan rekoleksi trauma (pikiran, perasaan, percakapan, aktivitas, tempat, orang).

5. Gejala kecemasan yang nyata atau peningkatan kesadaran (kewaspadaan berlebihan, sulit tidur, iritabilitas, konsentrasi buruk dan kegelisahan motorik).

6. Gangguan menyebabkan penderitaan yang bermakna secara klinis atau gangguan dalam fungsi sosial, pekerjaan atau fungsi penting lain mengganggu kemampuan individu untuk mengerjakan tugas yang diperlukan, seperti meminta bantuan yang diperlukan atau menggerakkan kemampuan pribadi dengan menceritakan kepada anggota keluarga tentang pengalaman traumatik.

7. Bukan efek fisiologis langsung dari suatu zat (obat yang disalahgunakan, medikasi) atau kondisi medis umum, tidak lebih baik diterangkan oleh gangguan psikotik singkat.

Sedangkan kriteria diagnostik untuk gangguan stres pascatrauma (PTSD), berdasarkan Diagnotic and Statistical Manual of Mental Disorders III-Revised (DSM III-R), dapat memperlihatkan kondisi traumatik seseorang adalah sebagai berikut :

1. Orang yang mengalami peristiwa luar biasa, dan dirasa amat menekan semua orang. Peristiwa traumatik itu secara menetap dapat dialami melalui cara teringat kembali peristiwa secara berulang dan sangat mengganggu, mimpi yang berulang tentang peristiwa yang membebani pikiran, perasaan atau tindakan mendadak seolaholah peristiwa traumatik itu terjadi lagi, tekanan jiwa yang amant sangat karena terpaku pada peristiwa yang melambangkan atau menyerupai traumatiknya.

2. Pengelakan yang menetap terhadap rangsang yang terkait dengan trauma atau kelumpuhan yang bereaksi terhadap situasi umum (yang tidak ada sebelum trauma itu). Keadaan ini paling tidak dapat ditunjukkan dengan sedikitnya 3 (tiga) dari keadaan yang berupa: upaya untuk mengelak terhadap gagasan atau perasaan yang terkait dengan trauma itu, upaya untuk mengelak dari kegiatan atau 
situasi yang menimbulkan ingatan terhadap trauma itu, ketidakmampuan untuk mengingat kembali aspek yang penting dari trauma, minat yang sangat berkurang terhadap kegiatan yang penting, rasa terasing dari orang lain, kurangnya afeksi, dan merasa tidak mempunyai masa depan.

3. Gejala meningginya kesiagaan yang menetap (tidak ada sebelum adanya trauma) dengan ditunjukkan oleh 2 (dua) dari gejala : sulit masuk fase tidur atau mempertahankan tidur yang cukup, iritable atau mudah marah, sulit berkonsetrasi, amat siaga, reaksi kejut (kaget) yang berlebihan, reaksi rentan faali saat menghadapi peristiwa yang melambangkan atau menyerupai aspek dari peristiwa traumatik.

4. Jangka waktu gangguan itu (gejala pada kriteria ke-2, ke-3 dan ke-4) sedikitnya 1 bulan.

Gangguan PTSD yang dialami individu akan berdampak pula pada kehidupan sosial. Hal ini dapat dilihat sebagai berikut :

1. PTSD memiliki gejala yang menyebabkan gangguan, umumnya gangguan tersebut adalah panic attack (serangan panik), perilaku menghindar, depresi, merasa disisihkan dan sendiri, merasa tidak percaya dan dikhianati, mudah marah, mengalami gangguan yang berarti dakan kehidupan sehari-hari.

2. Panic attack (serangan panik), khususnya pada anak atau remaja yang mempunyai pengalaman trau-matik dapat mengalami serangan panik ketika dihadapkan atau menghadapi pada sesuatu yang mengingatkan mereka pada trauma. Serangan panik meliputi perasaan yang kuat atas ketakutan atau tidak nyaman yang menyertai gejala fisik dan psikologis. Gejala fisik meliputi jantung berdebar-debar, berkeringat, gemetar, sesak nafas, sakit dada, sakit perut, merasa kedinginan, badan panas, mati rasa.
3. Perilaku menghindar. Salah satu gejala PTSD adalah menghindari halhal yang dapat mengingatkan penderita pada kejadian traumatis. Kadang-kadang penderita mengaitkan semua kejadian dalam kehidupannya setiap hari dengan trauma, padahal kondisi kehidupan sekarang jauh dari kondisi trauma yang pernah dialami. Hal ini sering menjadi lebih parah sehingga penderita menjadi takut untuk keluar rumah dan harus ditemani oleh orang lain jika harus ke luar rumah.

4. Depresi. Banyak orang menjadi depresi setelah mengalami peng-alaman traumatik dan menjadi tidak tertarik dengan hal-hal yang disenanginya sebelum peristiwa trauma. Penderita mengembangkan perasaan yang tidak benar, perasaan bersalah, menyalahkan diri sendiri dan merasa bahwa peristiwa yang dialaminya merupakan kesalahannya, walaupun semua itu tidak benar.

5. Memiliki pemikiran negatif. Kadangkadang orang yang sedang mengalami depresi merasakan bahwa kehidupannya sudah tidak berharga. Hasil penelitian menjelaskan bahwa 50\% korban kejahatan mempunyai pikiran untuk bunuh diri.

6. Merasa diri disisihkan. Penderita PTSD memerlukan dukungan dari lingkungan sosialnya tetapi mereka seringkali merasa sendiri dan terpisah. Perasaan yang demikian tersebut, umumnya penderita mengalami kesulitan untuk berhubungan dengan orang lain dan mendapatkan per-tolongan. Penderita sulit untuk percaya bahwa orang lain dapat memahami apa yang ia telah alami.

7. Merasa dirinya tidak percaya dan perasaan dikhianati. Setelah mengalami pengalaman yang menyedihkan, penderita mungkin kehilangan kepercayaan pada terhadap orang lain dan merasa dikhianati atau ditipu oleh 
lingkungan disekitarnya, atau oleh nasib, atau oleh Tuhan.

8. Perasaan marah dan mudah tersinggung. Marah dan mudah tersinggung adalah reaksi yang umum diantara penderita trauma. Marah adalah suatu reaksi yang wajar dan dapat dibenarkan. Bagaimanapun, kemarahan yang berlebihan dapat mempengaruhi proses penyembuhan dan menghambat penderita untuk berinteraksi dengan orang lain.

9. Gangguan yang berarti dalam kehidupan sehari-hari. Beberapa penderita PTSD mempunyai beberapa gangguan yang terkait dengan fungsi sosial dan gangguan di sekolah dalam jangka waktu yang lama setelah trauma. Seorang korban kejahatan mungkin menjadi sangat takut untuk ditinggal sendirian. Penderita mungkin kehilangan kemampuannya dalam berkonsentrasi dan melakukan tugasnya di sekolah. Bantuan perawatan pada penderita sangat penting agar permasalahan tidak berkembang lebih lanjut.

10. Persepsi dan kepercayaan yang aneh. Adakalanya seseorang yang telah mengalami trauma yang menyakitkan, seringkali untuk sementara dapat mengembangkan ide atau persepsi yang aneh, misalnya percaya bahwa dirinya bisa melihat atau berkomunikasi dengan orang-orang yang sudah meninggal. Walaupun gejala ini menakutkan, menyerupai halusinasi dan hayalan, gejala ini bersifat sementara dan dapat hilang dengan sendirinya.

2. Play Therapy Sebagai Model Intervensi Bagi Anak Korban Bencana Yang Mengalami PTSD.

Secara umum, terdapat 2 (dua) pendekatan terapi yang dapat dilakukan bagi penderita PTSD, yaitu dengan menggunakan farmakoterapi dan psikoterapi. Pengobatan dengan cara farmakoterapi, berupa terapi yang menggunakan obatobatan dan obat yang secara medis diper- bolehkan untuk dikonsumsi oleh penderita. Sedangkan pendekatan terapi yang menggunakan model psikologi atau yang dikenal dengan psikoterapi, bertujuan untuk memperbaiki fungsi sosial penderita.

Model penanganan bagi korban yang mengalami PTSD pada anak-anak tentu berbeda dengan orang dewasa. Pada anakanak model pendekatan yang dapat digunakan adalah dengan bermain, atau yang dikenal dengan istilah play therapy. Terapi bermain ini berguna dalam memberikan terapi pada anak yang mengalami PTSD. Biasanya terapis memakai permainan untuk memulai topik yang tidak dapat dimulai secara langsung. Hal ini dapat membantu anak lebih merasakan nyaman dalam berproses dengan pengalaman traumatiknya.

Pada umumnya anak-anak yang mengalami kondisi trauma menunjukkan simptom-simptom seperti ketakutan, cemas, sedih, menghindar dan kurang responsif terhadap beragam emosi. The Association for Play Therapy mendefinisikan play therapy sebagai berikut :

\section{"Process where in trainer play therapists use the therapeutic powers of play To help clients prevent or resolve psychosocial difficulties and achieve optimal growth and development".}

Berdasarkan pengertian yang dikemukakan tersebut, maka dapatlah diambil beberapa pengertian pokok sebagai landasan dalam melaksanakan play therapy, yaitu :

1. Play therapy dibangun berdasarkan pondasi teoritik yang sistimatis. Dalam kaitan ini, play therapy disusun dengan menggunakan kerangka teori psikologi dan konseling, misalnya Psikoanalisa, Client Centered, Gestalt, Cognitif Behavior, Adlerian, dan sebagainya.

2. Play therapy menekankan pada kekuatan permainan sebagai alat untuk membantu klien yang memerlukan bantuan. 
3. Tujuan dari penggunaan play therapy adalah untuk membantu klien dalam rangka mencegah dan mengatasi persoalan psikisnya serta membantu pencapaian pertumbuhan dan perkembangan sesuai dengan tugas perkembangannya secara optimal.

Konsep dasar yang dapat digunakan pada play therapy ini adalah mengacu pada pendangan sebagai berikut :

1. Bermain adalah salah satu cara yang dapat digunakan dalam memahami dunia anak-anak

2. Aspek perkembangan dalam kegiatan bermain merupakan cara anak dalam menemukan dan mengekplorasi identitas diri mereka

3. Anak dapat melakukan eksperimen dengan berbagai pilihan imajinatif dan terhindar dari konsekuensi seperti ketika di dunia nyata

4. Permainan pada situasi dan kondisi yang tepat dapat bermakna sebagai kegiatan fisik sekaligus sebagai terapi.

Axline (1947), menjelaskan bahwa penggunaan play therapy dilakukan dengan alasan bahwa bermain adalah media yang alami yang dapat digunakan anak untuk meng-ungkapkan dirinya. Selanjutnya dijelaskan pula bahwa bermain sebagai bahasa simbolik anak yang bersifat alami untuk menyatakan emosi dan pengalaman-pengalaman sehari-hari, bahkan bermain adalah proses penyembuhan diri anak. Dengan demikian bermain dapat membantu upaya menjalin hubungan dengan anak, membangun konsentrasi anak, meningkatkan kesehatan dan perkembangan anak.

Banyak keuntungan yang diperoleh dalam penggunaan play therapy, diantaranya:

1. Membantu proses perkembangan anak, dengan interaksi verbal yang minimal

2. Anak mendapatkan banyak kebebasan untuk memilih, mampu meningkatkan daya fantasi dan imajinasi anak, dapat menggunakan alat-alat sederhana, memberikan tempat yang aman bagi anak untuk mengekspresikan perasaan, mendapatkan pemahaman dan melakukan berbagai perubahan

3. Memudahkan konselor untuk membangun hubungan terapeutik dengan anak, juga dapat melatih keterampilan sosial anak

Menurut The Association for Play Therapy, terdapat 14 macam keuntungan yang diperoleh bila menggunakan play therapy sebagai sebuah intervensi, yaitu

1. Mengatasi resistensi. Anak-anak biasanya sulit untuk diajak konsultasi dengan konselor, apalagi mempunyai keinginan sendiri. Permainan adalah salah satu cara untuk menarik anak agar bisa terlibat dalam kegiatan konseling.

2. Komunikasi. Permainan adalah media alami yang digunakan anak untuk mengeskpresikan dirinya. Konselor bisa menggunakan berbagai pilihan permainan yang dapat memancing anak untuk dapat terus terlibat dalam permainan.

3. Kompetensi. Bermain memberikan kesempatan bagi anak untuk memenuhi kebutuhan anak untuk mengeksplorasi dan menguasai se-suatu keterampilan. Konselor bisa membangun kepercayaan dengan menunjukkan bahwa anak sedang melakukan kerja keras dan menunjukkan kemajuan.

4. Berpikir kreatif. Keterampilan problem solving dikembangkan, sehingga pemecahan atas persoalan anak bisa tercapai. Permainan memberikan peluang yang besar bagi anak untuk mengembangkan kemampuan diri untuk berpikir kreatif atas persoalan yang dialami.

5. Chatarsis. Melalui permainan anakanak dapat menyampaikan tekanan emosi yang dialaminya dengan lebih bebas, sehingga anak-anak bisa tumbuh dan berkembang secara optimal tanpa beban mental.

6. Abreaction. Dalam bermain, anak mendapat kesempatan untuk mem- 
proses dan menyesuaikan kesulitan yang pernah dialami secara simbolis dengan ekspresi emosi yang lebih tepat.

7. Role playing. Anak dapat mempraktekkan berbagai tingkah laku yang baru dan mengembangkan kemampuan empati dengan orang lain.

8. Fantacy. Anak-anak dapat menggunakan imajinasinya untuk mengerti akan pengalamannya yang menyakitkan. Mereka juga bisa mencoba mengubah hidup mereka secara perlahanlahan.

9. Metaphoric teaching. Anak-anak dapat memperoleh pengertian yang mendalam atas kesulitan dan ketakutan yang dialaminya dengan kiasan yang dimunculkan dalam permainan.

10. Attachment formation. Anak dapat mengembangkan suatu ikatan dengan konselor serta mengembangkan kemampuan untuk membangun koneksi dengan orang lain.

11. Peningkatan hubungan. Bermain dapat meningkatkan hubungan terapi yang positif, memberikan kebebasan anak untuk mewujudkan aktualisasi diri dan tumbuh semakin dekat dengan orang lain disekitarnya. Anak dapat mengenal cinta dan perhatian yang positif terhadap lingkungannya.

12. Emosi positif. Anak-anak menikmati permainan, dengan suasana hati ini mereka bisa tertawa dan mempunyai waktu yang menyenangkan di tempat yang mereka merasa diterima.

13. Menguasai ketakutan. Dengan permainan yang diulang-ulang akan mengurangi kegelisahan dan ketakut-an anak. Bekerja dengan mainan, seni dan media bermain lainnya mereka akan menemukan berbagai ke-terampilan dalam mengatasi ketakutan

14. Bermain game. Game membantu anak untuk bersosialisasi dan mengembangkan kekuatan egonya. Mereka mempunyai peluang untuk meningkatkan keterampilan
Sebagaimana definisi yang dikemukakan oleh The Association for Play Therapy keberadaan play therapy merupakan penerapan secara sistimatis beberapa teori konseling yang khusus diperuntukkan bagi anak-anak dengan mengandalkan kekuatan permainan dalam terapi. Play therapy merupakan pendekatan konseling yang menggunakan beberapa teknik yang diintegrasikan menjadi sebuah teknik terapi yang sesuai dengan kondisi anak yang menjadi korban bencana.

Untuk klien anak-anak digunakan permainan dan game untuk menarik anak, menjalin hubungan dan untuk menemukan petunjuk tentang diri anak yang sebenarnya. Konselor melibatkan anak-anak dalam berbagai kegiatan yang memungkinkan anak dapat me-ngemukakan kondisi psikologis yang dialaminya, seperti bermain bersama, bermain peran, atau memberikan kebebasan kepada anak untuk memainkan apa saja yang ia kehendaki.

Permainan adalah alat yang sangat efektif untuk menginterpretasikan bahasa simbolik yang disampaikan oleh anak melalui bahasa simbolik dalam sesi permainan. Permainan dapat memberikan pengaruh pada proses terapi melalui :

- Kegiatan mental, kesadaran atau ketidaksadaran, yang didalamnya terdapat hayalan dan harapan. Permainan juga merupakan aktifitas fisik yang dapat diobservasi.

- Permainan adalah sebuah kegiatan eksplorasi, sebuah sarana untuk menghidupkan kemauan untuk mencoba. Konselor berperan dalam hal menetapkan dan menjaga hubungan dengan anak, mengembangkan empati serta pemahaman.

- Merupakan proses awal, dalam rangka membangun hubungan dengan anak agar anak mampu mengungkapkan berbagai pengalaman masa lalunya yang tidak menyenangkan melalui pengintegrasian kemunculannya melalui bahasa simbol.

- Merupakan suatu cara yang digunakan untuk dapat mengupayakan renegosiasi 
hubungan anak dengan dirinya dan orang lain. Hal ini bertujuan untuk memecahkan fiksasi, regresi, kekurangan dalam perkembangan dan hambatanhambatan lain yang mengganggu perkembangan anak.

\section{Microskills Play Therapy}

Microskills merupakan keterampilan yang mutlak diperlukan dalam melakukan konseling. Untuk memperoleh keterampilan dasar itu, seorang konselor perlu memiliki keterampilan tersebut. Microskills dalam konseling anak-anak pada dasarnya sama dengan yang digunakan dalam konseling orang dewasa. Yang membedakannya adalah bagaimana konselor mampu menerapkan keterampilan dasar tersebut pada setting dunia anakanak. Konselor diharuskan mampu menyesuaikan proses konseling yang dilakukannya dengan karakteristik anak-anak, seperti kemampuan kognisi dan emosi, keterbatasan bahasa yang dimiliki dan sebagainya. Jika hal ini diperhatikan, maka konselor akan mudah menjalin komunikasi dengan anak. Jika komunikasi lancar, konseling yang dilakukan pun akan lancar, dalam pengertian tidak mengalami hambatan dan bisa membantu anak dalam menemukan hidup seperti yang semestinya.

Keterampilan microskills yang diperlukan saat melakukan konseling pada anak-anak, terutama berpusat pada :

1. Refleksi content dan feeling.

Hal yang terpenting yang dilakukan oleh konselor pada bagian ini adalah bagaimana ia bisa membangun komunikasi dengan anak dalam rangka menyampaikan kesepahaman berkaitan dengan isi dan perasaan yang ada dalam diri anak. Sedangkan untuk orang dewasa, metode ini bisa dilakukan dengan komunikasi verbal. Tetapi, karena anak mempunyai keterbatasan bahasa verbal untuk menyampaikan sesuatu, dan ia sering mengungkapkan perasaannya melalui aktifitas dan bermain, maka konselor harus bisa menggunakan sarana itu.
Untuk dapat membangun komunikasi dengan anak, konselor bisa melakukan dengan cara mengikuti apa yang dilakukan anak, yang dikenal dengan istilah behavior tracking. Dengan behavior tracking ini, konselor mengikuti bahkan bisa berpartisipasi dalam apa yang dilakukan anak. Dengan cara ini konselor bisa menggali apa saja yang sedang dirasakan anak, yang dalam kondisi normal mungkin ia akan sulit mengkomunikasikannya dengan orang dewasa. Dasar dari content yang akan yang akan digali konselor dalam melakukan konseling dengan anak-anak adalah emosi, yaitu bagaimana anak mampu mengungkapkan perasaan yang ada dalam dirinya. Hanya saja anak-anak seringkali kekurangan kosa kata untuk mampu mengungkapkan seluruh perasaannya.

Hindari bertanya atau meminta pada anak untuk mengungkapkan perasaannya adalah sesuatu yang tidak produktif. Tapi gunakanlah cara menggali informasi yang dibutuhkan dengan bahasa non verbal, misalnya dengan mengkaitkan suatu aktifitas dengan sesuatu yang dilihatnya. Selain itu, konselor harus mempunyai kesabaran dan ketelatenan yang tinggi, karena selain anak-anak mengalami kesulitan dalam menyampaikan ungkapan secara verbal, boleh jadi anakanak telah mendapatkan pesan atau pengajaran dari keluarganya untuk menyembunyikan perasaannya.

2. Refleksi meaning, interpretasi dan penggunaan metafora.

Ketika berkomunikasi dengan orang dewasa, konselor bisa menggali secara tepat terhadap hal-hal apa saja yang diungkapkan klien, konselor pun bisa meminta klien untuk mengulangi dengan memberikan pertanyaan yang sama. Namun ketika berkomunikasi dengan anak-anak dalam suatu proses konseling, pertanyaan yang sama bisa membuat klien anak merasa enggan 
menjawab. Keterampilan menggunakan metafora penting dilakukan bila menghadapi klien anak. Penggunaan metafora ini misalkan dengan mengasosiasikan maksud yang hendak digali dari diri anak melalui permainan yang menjadi kesukaannya.

Manfaat metafora ini dapat membantu konselor dalam menghadapi klien anak yang mengalami kesulitan dalam berkomunikasi. Teknik yang digunakan dalam metafora juga bermanfaat untuk 'mem-bypass' resistensi klien, memfasilitasi kesadaran yang berhubungan dengan emosi, keyakinan dan memperkenalkan berbagai kemungkinan dan perspektif baru. Ketika anak sudah mampu menyatakan tentang dirinya dengan bebas melalui hayalan, maka konselor dapat terus mengarahkan agar ungkapan melalui hayalan dan simbolik bisa mengarah pada kenyataan, yaitu kenyataan hidup yang dialami anak. Langkah-langkah ini bisa digunakan untuk mengintegrasikan dengan cerita ketika anak menggambarkan dirinya dan orang lain melalui karakter dalam cerita tersebut, kemudian hal ini bisa dikembangkan untuk mendapatkan pengertian yang mendalam tentang masalah yang dihadapi anak.

Digunakan atau tidaknya makna interpretasi meaning sangat ditentukan oleh orientasi teori yang dianut oleh konselor. Dengan demikian konselor sangat dituntut untuk memiliki pengetahuan yang mendalam yang berkaitan dengan psikologi perkembangan anak. Dengan penguasaan yang mendalam tentang persoalan ini konselor akan mudah memahami apa yang digambarkan anak melalui cerita hayalannya, juga memudahkan bagi konselor dalam menanamkan pengetahuan diri anak.

\section{Langkah-langkah Play Therapy.}

Disamping memperhatikan keterampilan dasar dalam melakukan konseling dengan klien anak, perlu diperhatikan prosesnya. Proses ini menandakan hubungan yang terjadi sepanjang kegiatan konseling berjalan yang didalamnya mencakup upaya konselor dalam menyarankan berbagai perubahan, juga berkaitan dengan cara konselor dalam membangun hubungan yang penuh dengan kepercayaan dari anak. Salah satu cara yang dapat digunakan untuk memperoleh kepercayaan dari anak adalah melalui acticve listening dan unconditional acceptance.

Fokus yang hendak yang dicapai dalam hal ini adalah terjadinya perubahan atas tingkah laku anak yang menyimpang, yang dapat membantu konselor dalam melihat pergerakan dan kemajuan yang dicapai. Melalui media bermain seperti cat, tanah liat dan air, anak-anak menyatakan dirinya secara kiasan dan simbolik. Oleh karenanya dengan mengetahui langkahlangkah dan tema dalam konseling anak, dapat membantu konselor dalam proses konseling yang dilakukannya.

Langkah-langkah yang perlu diketahui dan dilaksanakan dalam kegiatan ini meliputi :

1. Mengenal langkah-langkah konseling anak.

Hal pokok yang harus disadari oleh para konselor, yaitu setting, struktur sesi atau pertemuan yang disesuaikan dengan dunia anak-anak. Terdapat 3 (tiga) fase yang perlu diperhatikan ketika konselor akan berinteraksi dengan anak-anak, yaitu: a. Langkah awal.

Dalam tahap awal ini, kegiatan utamanya adalah bagaimana membangun hubungan anak-konselor. Konselor harus mampu membangun hubungan yang hangat, yang didalamnya ada kepercayaan anak terhadap konselor. Untuk mencapai tujuan tersebut, konselor harus berusaha masuk secara total pada dunia anak, sehingga anak betul-betul merasa aman dan menganggapnya sebagai sahabat.

Langkah ini bisa dilakukan oleh konselor dengan menyediakan berbagai permainan yang digemari anak. Melalui fasilitas permainan ini konselor bisa mengajar anak-anak ber- 
main dengan tujuan agar anak merasa aman. Ketika anak sudah merasa aman, konselor bisa menyiapkan berbagai perangkat konseling dalam menggali berbagai gejala dan informasi yang ia butuhkan, yang ditunjukkan anak melalui berbagai aktifitas komunikasi dan interaksi termasuk didalamnya aktifitas bermain mereka.

b. Langkah pertengahan.

Langkah pertengahan dimulai ketika anak sudah asyik dengan permainan dan perhatian mereka. Konselor dapat memfasilitasi kegiatan ini dengan menyediakan berbagai sarana bermain agar anak dapat mengekspresikan berbagai perasaan baik sesuatu yang pernah dialaminya di masa lampau atau keinginan yang ia harapkan pada masa yang akan datang.

Pada kondisi ini konselor bisa melibatkan diri pada aktifitas yang sedang dilakukan anak, misalnya anak yang sedang menggambar, konselor bisa melakukan eksplorasi berbagai informasi yang dibutuhkan melalui upaya terlibat langsung dengan aktifitas yang sedang dilakukan anak. Melalui menggambar anak akan mengekspresikan suasana emosinya.

Konselor bisa juga menggunakan cerita dengan karakter pelaku cerita orang-orang yang ada dalam kehidupan anak, dengan permasalahan yang serupa dengan apa yang dialami anak. Melalui teknik ini, konselor dapat membantu anak untuk mengembangkan kreatifitasnya secara lebih luas, seperti kemampuan bahasa, seni, gerak, drama dan dapat mengembangkan kemampuan emosi anak dalam menjalin hubungan dengan alam sekitarnya.

c. Langkah akhir.

Pada tahap ini konselor dapat mengakhiri proses konseling bila pada diri anak telah menunjukkan kemajuan dalam berbagai bentuk perilaku positif. Bila anak telah mampu me- nunjukkan kebutuhan minimalnya, secara simbolik mampu mengekspresikan emosinya dan secara lisan mampu mendiskusikan berbagai isu. Konseling dapat dihentikan bila anak telah mampu menunjukkan kreatifitasnya dalam seni, mampu bermain peran, melakukan permainan yang melibatkan kerjasama dengan teman sebayanya, atau menampilkan perubahan perilaku yang positif lainnya.

\section{Mengidentifikasi Tema Konseling Anak}

Perbedaan jenis kelamin sangat berpengaruh terhadap pola dan tema permainan anak. Dari hasil penelitian yang telah dilakukan oleh seorang ahli terhadap anak laki-laki dan perempuan dengan latar belakang keluarga yang tidak harmonis, sering terjadi pertengkaran antara ayah dan ibunya dan berujung pada perceraian. Hasil penelitian tersebut menunjukkan bahwa anak laki-laki cenderung menyukai permainan dengan tema agresi atau kekerasan dibanding dengan anak perempuan.

Terdapat 3 (tiga ) tema besar yang dapat digunakan sebagai bahan pendekatan dalam melaksanakan konseling anak, yaitu:

a. Sebagian anak mempunyai kecenderungan untuk menyukai bentuk permainan agresif dan meng-andalkan kekuatan. Bentuk-bentuk permainan dalam katagori ini adalah permainan yang melibatkan keaktifan anak, pelibatan energi tinggi, permainan gross motor dan permainan kata tegas (assertive verbalization). Konselor bisa mengajak anak untuk bermain dengan permainan-permainan seperti bermain tentara-tentaraan, memukul drum, melempar pasir, dan sebagainya. Fokusnya adalah bagai-mana anak bisa menyalurkan energi-nya yang tinggi untuk dijadikan sebagai sarana emosinya yang ter-tekan.

b. Tema keluarga. 
Anak-anak juga mempunyai kecenderungan untuk menyukai permainan yang bertemakan keluarga atau kepengasuhan. Konselor bisa menggunakan boneka, figur binatang dan figur dalam permainan drama.

c. Tema safety atau security.

Permainan dengan tema keselamatan dan keamanan difokuskan pada upaya anak untuk menghadirkan figur karakter yang menyelematkan dan menjaga ke-amanan. Mungkin anak bisa bermain dengan membuat sangkar binatang, kemudian ia menyembunyikan figur yang berbahaya yang mengancam keselamatan binatang peliharaannya, kemudian ia menghadirkan figur pe-nyelamat yang bisa menghindarkan ancaman. Figur pahlawan bisa dimainkan oleh dirinya sendiri atau figur lain yang menjadi idolanya.

\section{Mengidentifikasi Perilaku Yang Akan Diubah.}

Anak atau remaja yang mempunyai pengalaman trauma, dapat mengalami serangan panik ketika dihadapkan pada sesuatu yang mengingatkan mereka pada trauma. Serangan panik meliputi perasaan yang kuat atas ketakutan atau rasa tidak nyaman yang menyertai gejala fisik dan psikologis. Gejala fisik meliputi jantung berdebar, berkeringat, gemetar, sesak napas, sakit dada, sakit perut, pusing, merasa kedinginan, badan terasa panas, mati rasa.

Beberapa perilaku yang sering diperlihatkan oleh anak atau remaja yang mengalami trauma, diantaranya :

a. Perilaku menghindar.

Salah satu gejala PTSD adalah menghindari hal-hal yang dapat mengingatkan penderita pada kejadian traumatis. Kadang-kadang penderita mengkaitkan semua kejadian dalam kehidupannya setiap hari dengan trauma, padahal kondisi kehidupan sekarang jauh dari kondisi saat trauma yang dialaminya. Hal ini sering menjadi lebih parah sehingga penderita menjadi takut untuk keluar rumah dan harus ditemani oleh orang lain jika harus keluar rumah.

b. Depresi.

Banyak penderita mengalami depresi setelah mengalami pengalaman trauma dan menjadi tidak tertarik dengan hal-hal yang disenanginya sebelum peristiwa trauma. Mereka mengembangkan perasaan yang tidak benar, perasaan bersalah, menyalahkan diri sendiri, dan merasa peristiwa yang dialaminya merupakan kesalahannya, walaupun semua itu tidaklah benar.

c. Kecenderungan ingin bunuh diri.

Kadang-kadang orang yang depresi berat merasa bahwa kehidupannya sudah tidak berharga. Hasil penelitian yang dilakukan para ahli, ditemukan bahwa 50\% korban kejahatan mempunyai pikiran untuk bunuh diri.

d. Merasa disisihkan dan sendiri.

Penderita PTSD memerlukan dukungan dari lingkungan sosialnya tetapi mereka seringkali merasa sendiri dan terpisah. Perasaan yang bersifat negatif ini membuat mereka mengalami kesulitan untuk berhubungan dengan orang lain dan mendapatkan pertolongan. Penderita sulit untuk percaya bahwa orang lain dapat memahami apa yang telah ia alami.

e. Merasa tidak percaya dan dikhianati.

Setelah mengalami pengalaman yang menyedihkan, penderita mungkin akan kehilangan kepercayaan terhadap orang lain dan merasa dikhianati atau ditipu oleh dunia, nasib atau Tuhan.

f. Marah dan mudah tersinggung.

Marah dan mudah tersinggung adalah reaksi yang umum diantara penderita trauma. Bagaimanapun kemarahan yang berlebihan dapat mempengaruhi proses penyembuhan dan menghambat penderita untuk berinteraksi dengan orang lain di rumah dan di tempat terapi.

g. Gangguan yang berarti dalam kehidupan sehari-hari. 
Penderita PTSD mempunyai beberapa gangguan yang terkait dengan fungsi sosial dan gangguan penyesuaian di sekolah dalam jangka waktu yang lama setelah trauma. Seorang korban kejahatan mungkin menjadi sangat takut untuk tinggal sendirian. Penderita mungkin kehilangan kemampuannya dalam berkonsentrasi dan melakukan tugasnya di sekolah. Bantuan dan perawatan pada penderita sangat penting agar permasalahannya tidak berkembang lebih lanjut.

h. Persepsi dan kepercayaan yang aneh.

Adakalanya seseorang yang telah mengalami trauma yang menyakitkan, seringkali untuk sementara waktu mengembangkan ide atau persepsi yang aneh, misalnya ia mempercayai bahwa ia bisa melakukan komunikasi atau melihat orang-orang yang sudah meninggal. Walaupun gejala ini menakutkan, menyerupai halusinasi atau hayalan, gejala ini bersifat sementara dan akan menghilang dengan sendirinya.

\section{Pelaksanaan Konseling Kelompok Pada Anak-anak (Group Counseling)}

Masa anak-anak adalah masa bermain. Pada masa ini tumbuh minat terhadap teman sebaya, sehingga anakanak seringkali menghabiskan waktunya dengan bermain dengan teman sebayanya. Ketika seorang anak menjalin interaksi dengan teman sebaya, ia akan mempelajari berbagai keterampilan sosial yang dibutuhkan, diantaranya berkomunikasi, mengembangkan inisiatif, persaingan, dan sebagainya. Anak-anak menerima umpan balik tentang kemampuan-kemampuan mereka dari kelompok teman sebaya. Anak-anak mengevaluasi apa yang mereka lakukan dalam arti apakah ini lebih baik daripada apa yang dilakukan oleh anakanak lain.

Dengan demikian, banyak hal yang akan diperoleh manfaatnya bagi anak-anak ketika berada dalam kelompok. Kondisi serta manfaat kelompoklah yang mendasari mengapa konseling yang diberikan pada anak-anak yang mengalami trauma dilaksanakan dalam kelompok.

Konseling kelompok adalah suatu bentuk konseling yang dilakukan dalam kelompok-kelompok kecil. Anggota kelompok berjumlah antara 6 sampai 10 orang. Anggota kelompok diseleksi dengan hati-hati. Pertemuan dengan konselor dilakukan secara berkala dan terjadual. Dalam pelaksanaannya anggota kelompok ditumbuhkan motivasinya untuk memberikan umpan balik pada anggota lainnya, menanggapi termasuk mengekspresikan perasaan mereka mengenai apa yang dikatakan atau dilakukan anggota lain. Interaksi antara anggota kelompok sangat mendorong dan memberikan setiap orang dengan sebuah kesempatan untuk mencoba cara baru dalam berperilaku, juga memberikan kesempatan pada anggota untuk belajar lebih lanjut tentang cara berinteralsi dengan orang lain.

Konselong kelompok merupakan lingkungan yang aman untuk membangun tingkat kepercayaan yang menungkinkan mereka untuk berbicara secara pribadi dan jujur. Anggota kelompok membuat suatu komitmen dan diinstruksikan bahwa isi pembicaraan dalam kelompok adalah bersifat rahasia dan tidak dibenarkan bagi anggota kelompok untuk mengungkapkan kejadian-kejadian dalam kelompok kepada pihak lain di luar kelompok tersebut.

\subsection{Tahap Pembentukan Kelompok}

Tahap pembentukan kelompok ini merupakan langkah awal ini adalah sebuah pertemuan yang diasumsikan sebagai pertemuan pertama antara konselor dan peserta konseling (anak). Oleh karenanya langkah pertama yang harus dilakukan adalah membangun keakraban dengan anak melalui attending. Tujuan akhir dan langkah awal ini adalah anak merasa aman ketika bersama konselor. Konselor tidak lagi dianggap sebagai sosok yang membawa ancaman, tapi sebaliknya, konselor telah dianggap sebagai individu yang menyenangkan, melindungi dan bersahabat dengan anak. Dengan adanya keterbatasan bahasa verbal yang dimiliki 
anak, maka permainan adalah bahasa simbolik yang lebih tepat.

Pada tahap ini perlu kiranya diperhatikan beberapa langkah yang dipersiapkan dalam membentuk kelompok, yaitu :

1. Sebelum konseling dimulai, konselor perlu berdiskusi terlebih dahulu dengan orang tua, atau pengasuh anak atau pihak-pihak lain yang mempunyai kedekatan emosional dengan anak untuk mendapatkan beberapa informasi yang terkait dengan karakteristik anak.

2. Disarankan konselor anak memiliki ruangan khusus yang didesain sebagai kamar bermain dan memenuhi standar keamanan bagi anak-anak

3. Plihlah permainan yang disukai anakanak (hal ini bisa ditanyakan terlebih dahulu pada anak tersebut)

4. Ajaklah anak-anak tersebut bermain, dalam hal ini konselor harus proaktif dan menunjukkan kesan bersungguhsungguh serta melakukan observasi terhadap seluruh kejadian yang berlangsung. Melalui permainan suasana kelompok akan lebih mudah lebur, sehingga akan mudah menjalin kedekatan atau keakraban. Dengan demikian konselor perlu kemahiran dalam merancang permainan kelompok.

5. Lakukan percakapan yang ringan, dengan tujuan untuk menarik anak-anak memiliki kedekatan emosional dengan konselor.

6. Berupaya agar bisa dianggap oleh anakanak sebagai sahabat yang menyenangkan, sebagai tempat untuk berlindung bagi mereka.

7. Ketika sudah merasakan bahwa anakanak sudah dekat dengan konselor, maka konselor dapat melanjutkan pada fase berikutnya, yaitu mengeksplorasi perasaan dan persoalan yang sedang dihadapi anak. Pada langkah ini memudahkan bagi konselor untuk menegakkan diagnosis suatu ganggun yang dialami anak.

Bila sudah terbangun pembentukan struktur kelompok, terdapat beberapa langkah berikutnya yang perlu mendapat perhatian, mengingat kondisi anak sedang dalam situasi yang tertekan, yaitu :

1. Gunakan permainan yang memungkinkan bagi konselor untuk banyak berdialog dengan anak, misalnya menggambar, permainan alat bongkar-pasang, boneka tangan, dan sebagainya.

2. Tentukan pilihan permainan dengan melibatkan anak.

3. Sambil bermain bersama, konselor dapat menyampaikan beberapa pertanyaan yang kira-kira bisa mengungkap perasaan apa yang sedang dirasakan anak. Informasi yang diperoleh melalui orang tua atau pengasuh dapat pula dijadikan referensi.

4. Membuat catatan-catatan hasil dialog konselor dengan anak untuk dijadikan sebagai alat untuk mengidentifikasikan apa saja kelebihan-kelebihan yang dimiliki anak, permasalahan yang dialami anak.

5. Setelah konselor dapat mengidentifikasikan masalah yang dialami anak, konselor dapat masuk pada fase berikutnya, yaitu mengatasi permasalahan anak.

\section{PENUTUP}

Sebagaimana hal yang telah diungkapkan pada awal tulisan ini, bahwa penanganan yang diperlukan bagi korban bencana yang mengalami PTSD baik bagi orang dewasa maupun anak-anak memiliki cara pendekatan yang berbeda. Bagi anakanak yang mengalami PTSD teknik yang sesuai untuk mengatasi kondisi trauma adalah dengan menggunakan teknik Play Therapy. Masa anak-anak adalah masa usia bermain, maka aspek ini menjadi salah satu faktor pertimbangan bagi konselor didalam merancang teknik konseling yang digunakan. Permainan pada situasi dan kondisi yang tepat dapat bermakna sebagai kegiatan fisik sekaligus sebagai terapi. Selain itu, pada masa anakanak, bermain dalam kelompok merupakan kegiatan yang diminati anak-anak, se- 
hingga kelompok pun dapat berfungsi untuk mengembangkan keterampilan sosial pada anak-anak.

Setelah anak-anak korban bencana mengikuti sesi konseling, tentu saja diharapkan anak yang mengalami trauma menunjukkan perubahan yang ke arah positif setelah mengikuti konseling. Ketika anak telah menunjukkan perubahan perilaku ke arah yang positif, konselor dapat mengakhiri permainan dan apabila diperlukan konselor dapat membuat janji untuk mengikuti sesi konseling berikutnya. Orang tua atau pengasuh dapat tetap dilibatkan pada upaya penanganan permasalahan anak, dengan selalu memberikan permainan yang serupa kepada anak, selain itu agar orang tua atau pengasuh dapat terus mendampingi ketika anak sedang bermain dengan cara memberikan berbagai stimulasi yang sudah diberikan contohnya oleh konselor.

Sebagai tindak lanjut dari proses konseling tersebut, konselor dapat memberikan pemahaman pada orang tua atau pengasuh, diantaranya :

1. Orang tua atau pengasuh memberikan perhatian pada anak dengan cara mendampingi aktifitas bermain anak sehari-hari.

2. Buatlah kesan yang mendalam agar anak merindukan kebersamaannya dengan orang tua atau peng-asuhnya.

3. Orang tua dapat mengulangi sesi bermain dengan permainan yang berbeda, tetapi memberikan stimulasi pada wilayah perkembangan yang sama (yang sesuai dengan permasalahan anak).

\section{DAFTAR PUSTAKA}

Axline, Virginia, 1947, Play Therapy: The Inner Dynamics of Childhood, $1^{\text {st }}$ ed, John Wiley \& sons.
Brammer, Lawrence M. 1979. The Helping Relationship, second edition, Prentice-Hall, Inc., englewood Cliffs, New Jersey.

Corey, Gerad, Teori dan Praktek Konseling dan Psikoterapi, Penerbit Refika Aditama, 2003.

Davidson, Gerald. C, Psikologi Abnormal, edisi ke-9, PT. Rajawali Press, 2006.

Geldard, David, 1993. Basic Personal Counseling : a training manual for counselors, second edition. PrenticeHall of Australia Pty Ltd, Australia.

Ivey, Allen,E.1980. Counseling and Psychotherapy : Skills, Theories, and Practice. Prentice-Hall, Inc., Englewood Cliffs, New Jersey.

Kurnanto M. Edi, Situs Konseling STAIN Pontianak, Play Therapy Intervensi Konseling yang tepat untuk anak.

Nevid, Jeffrey, S. (penerjemah Tim Fakultas Psikologi Indonesia), Psikologi Abnormal, 2003, Penerbit Erlangga, Jakarta.

Paterson, Cecil Holden., 1986, Theories Of Counseling and Psychotherapy, $4^{\text {th }}$ ed, Harper \& Row, Publisher, New York

Yalom, ID., 1985, The Theory and Practice of Group Psychotherapy, $4^{\text {th }}$ ed, New York : Basic Book, Inc

W. Yurika F., Lestari W. Gangguan Stres Pasca Trauma Pada Korban pelecehan Seksual dan Perkosaan, Pusat Penelitian dan Pengembangan Sistem dan Kebijakan Kesehatan, Surabaya, 2003. 